\title{
Quinonoids: Therapeutic Potential for Lung Cancer Treatment
}

\author{
Hua-Zhong Ying, ${ }^{1}$ Chen-Huan Yu $\mathbb{D}^{1},{ }^{1}$ Hao-Kun Chen, ${ }^{1}$ Huan-Huan Zhang $\mathbb{D},{ }^{1}$ Jie Fang, \\ Fang $\mathrm{Wu},{ }^{1}$ and Wen-Ying $\mathrm{Yu} \mathbb{C}^{1,2}$ \\ ${ }^{1}$ Key Laboratory of Experimental Animal and Safety Evaluation, Hangzhou Medical College, Hangzhou 310013, China \\ ${ }^{2}$ Key Laboratory of Neuropsychiatric Drug Research of Zhejiang Province, Institute of Materia Medica, Hangzhou Medical College, \\ Hangzhou 310013, China
}

Correspondence should be addressed to Wen-Ying Yu; zjyuwenying@163.com

Received 11 November 2019; Accepted 30 March 2020; Published 7 April 2020

Academic Editor: Changyang Gong

Copyright (c) 2020 Hua-Zhong Ying et al. This is an open access article distributed under the Creative Commons Attribution License, which permits unrestricted use, distribution, and reproduction in any medium, provided the original work is properly cited.

\begin{abstract}
Lung cancer is the leading cause of cancer-related deaths worldwide. Owing to its high incidence and mortality, the development and discovery of novel anticancer drugs is of great importance. In recent years, many breakthroughs have been achieved in the search for effective anticancer substances from natural products. Many anticancer drugs used clinically and proven to be effective are derived from natural products. Quinonoids, including naphthoquinones, phenanthrenequinones, benzoquinones, and anthraquinones, constitute a large group of natural bioactive compounds that widely exist in higher and lower plant species. Given that most of these compounds possess anticancer effects, they are applied in many cancer studies, especially in lung cancer research. They can promote apoptosis, induce autophagy, and inhibit proliferation, angiogenesis, and cell invasion and migration. Some drugs can enhance anticancer effects when combined with other drugs. Thus, quinonoids have broad application prospects in the treatment of lung cancer. Here, we summarize the previous studies on the antilung cancer activities of quinonoids together with their underlying mechanisms and analyze the common research targets with different effects so as to provide references for the discovery of quinonoids against lung cancer.
\end{abstract}

\section{Introduction}

Lung cancer is the leading cause of cancer-related deaths worldwide, and the incidence rate showed an increasing trend. The onset of lung cancer is relatively insidious. Most patients are diagnosed late and thus lose the chance to undergo operation. Chemoradiotherapy remains the main treatment method, which can alleviate the illness but has serious side effects [1]. Therefore, searching for safer and more effective antilung cancer drugs is necessary. Natural products are a rich source of discovery and development of antilung cancer drugs. With the emergence and improvement of new technologies, such as genetic techniques, combinatorial chemistry technology, and high-throughput screening for plant secondary metabolite production, safe and effective antilung cancer drugs can be identified and developed from natural sources (including medicinal plants). A large number of preclinical and clinical studies have confirmed that many natural products have potential antilung cancer properties [2]. Thus, developing natural antilung cancer products is important.

Quinonoids are a large group of natural bioactive molecules with unsaturated cyclodiketone structures (quinone structures) [3]. They possess extensive biological activities, such as antidiarrheal, bactericidal, anti-inflammatory, and antiviral activities; inhibit tumor growth and coronary artery expansion; alleviate ultraviolet radiation damage; and improve immune function [3, 4]. Quinonoids serve as vital links in electron transport chains in the metabolic pathway, participating in multiple biological oxidative processes. This redox characteristic accounts for the inherent cytotoxicity of quinonoids. Quinonoids have constituted the largest class of cytotoxins used as anticancer drugs and are frequently used in lung cancer research [5]. Their mechanisms involve a variety of pathways that promote apoptosis, induce autophagy, and inhibit proliferation, angiogenesis, cell invasion, and 
metastasis. However, the anticancer effects of many quinonoids, especially those against lung cancer, have not been clarified. In the present review, we introduce the distribution of quinonoid plant resources, summarize the antilung cancer activities and underlying mechanisms of quinonoids, and analyze the common targets with different effects to promote the research and development of antilung cancer agents from quinonoids.

\section{Distribution of Quinonoid Plant Resources}

Quinonoids are mainly classified into four types: benzoquinones, naphthoquinones, phenanthrenequinones, and anthraquinones. Among them, anthraquinones and their derivatives are the most common natural active ingredients. Natural quinonoids are widely distributed in more than 100 species of higher and lower plants, many of which are common Chinese herbal medicines. The distribution of common quinonoid plant resources is shown in Table 1.

\section{Quinonoids in Lung Cancer}

In recent years, significant amounts of studies have shown that quinonoids have obvious antilung cancer effect. Table 2 summarizes some antilung cancer quinonoids and their plant sources. The mechanisms are mainly as follows: inhibition of lung cancer cell growth and proliferation, initiation of apoptosis and autophagy, induction of antiangiogenesis, reduction of invasion and metastasis, and enhancement of chemosensitivity.

3.1. Quinonoids Inhibit Proliferation and Induce Apoptosis or Necrosis. Proliferation-related pathways affected by quinonoids mainly include the PI3K/Akt, Ras/MAPK, and JAK/STAT pathways, which are often disordered in cancer progression and thus promote the growth and proliferation of cancer cells. Quinonoids can regulate the cell cycle control system involved in lung cancer progression. This system mainly includes cell cycle protein (cyclin), cyclindependent kinases (CDKs), and cyclin-dependent kinase inhibitors (CKIs).

In A549 lung cancer cells, the natural product embelin can inhibit lung cancer through oxidative stress-induced MAPK signaling transduction. The levels of p-p38 and pJNK are elevated as early as $4 \mathrm{~h}$ after embelin administration, resulting in cell apoptosis [6].

Emodin is an anthraquinone derivative from the rhizome of rhubarb and possesses potent anticancer activities. In A549 cells, emodin can induce cell cycle arrest and modify an exogenous apoptotic pathway to inhibit cell growth and initiate apoptosis. Apoptotic characteristics, such as DNA single-strand breakage and DNA fragmentation, are observed in emodin-treated A549 cells. Meanwhile, emodin can upregulate FasL gene expression and downregulate cMyc cancer gene expression [7]. In addition, emodin can inhibit Anip973 cell proliferation, arrest cell cycle in the G0/G1 stage, decrease the cell proportion at $S$ phase, and trigger the activation of caspase-3, thus inhibiting tumor growth in a dose- and time-dependent pattern [8]. Su et al. [9] found that tribbles homolog 3 (TRIB3) signaling is associated with emodin-induced ER stress-mediated apoptosis in human non-small-cell lung cancer (NSCLC) cell lines. Emodininduced apoptotic effect decreases by inhibition of ER stress with 4-phenylbutyrate. When TRIB3 is silenced by siRNA, emodin-induced apoptosis is also weakened.

Oxidative damage caused by reactive oxygen species (ROS) plays a crucial role in the emodin-induced apoptosis of mitochondria. Emodin activates the ATM/p53/Bax dependent pathway by inducing ROS generation. The p53 protein increases in A549 cells, which in turn upregulates the level of Bax, and these effects lead to mitochondrial-dependent apoptosis in A549 cells [10]. Additionally, emodin can mediate the production of peroxidase proliferator-activated receptor $\gamma(\operatorname{PPAR} \gamma)$ through ERK and adenosine $5^{\prime}$-monophosphate-dependent protein kinase $\alpha$ (AMPK $\alpha)$, followed by the reduction of pregnancy-specific $\beta 1$-glycoprotein (SP1). This in turn induces insulin-like growth factor binding protein 1 (IGFBP1) gene expression. Thus, synergistic interactions among signal cascade, positive feedback loop, and transcription factors may contribute to the overall responses of emodin on NSCLC cells [11]. Some studies have found that emodin may inhibit NSCLC cell proliferation by downregulating the expressions of excision repair crosscomplementary 1 (ERCC1) and DNA repair protein RAD51 homolog 1 (Rad51) with a dose-dependent pattern. The downregulation of these two proteins is associated with the inactivation of the MKK1/2-ERK1/2 signaling pathway $[12,13]$. Besides, emodin can inhibit the transcription effect transactivated by the homolog and heterodimer of retinoic acid $\mathrm{X}$ receptor $\alpha(\mathrm{RXR} \alpha)$. The exhibition of emodin and its anticancer activity may be associated with the RXR $\alpha$ signaling pathway [14].

Plumbagin is a nature naphthoquinone isolated from three families, namely, Droseraceae, Ebenaceae, and Plumbaginaceae, and can inhibit cell proliferation and induce apoptosis in NSCLC cells via NF- $\kappa$ B inactivation. Plumbagin treatment increases the intracellular ROS level; suppresses the activation of $\mathrm{NK}-\kappa \mathrm{B}$; inhibits the degradation of $\mathrm{I} \kappa \mathrm{B} \kappa$; downregulates the expression of $\mathrm{Bcl}-2$; upregulates the expression of Bak, Bax, and CytC; and promotes the activities of caspase-9 and caspase-3 [15].

$\beta$, $\beta$-Dimethylacrylshikonin is one of the active components in the root extracts of Lithospermum erythrorhizon. This compound suppresses cell viability in A549 cells at doseand time-dependent fashion. It can downregulate the expression of the cell inhibitor of apoptosis protein-2 (cIAP-2) and $\mathrm{X}$-linked inhibitor of apoptosis protein (XIAP) and upregulate the levels of Bax and Bak to induce apoptosis of A549 cells. Moreover, $\beta, \beta$-dimethylacrylshikonin promotes the loss of mitochondrial membrane potential (MMP) and release of CytC in A549 cells; activates caspase-3, caspase-8, and caspase-9; and then cleaves poly ADP-ribose polymerase (PARP) [16].

Chrysophanol is an anthraquinone compound and has been found to induce different types of cancer cell death. It can promote the release of ROS and $\mathrm{Ca}^{2+}$ in A549 cells, decrease MMP and adenosine triphosphate level, trigger DNA damage, and stimulate the release of CytC, but it does 
TABLE 1: Distribution of common quinonoid plant resources $[3,4]$.

\begin{tabular}{|c|c|c|c|c|}
\hline Type & No. & Latin name & Families & Quinonoids in plants \\
\hline \multirow{6}{*}{ Benzoquinones } & 1 & Embelia laeta & Myrsinaceae & Embelin \\
\hline & 2 & Ardisia oxyphylla & Myrsinaceae & Embelin, rapanone \\
\hline & 3 & Ardisia crenata & Primulaceae & Rapanone \\
\hline & 4 & Ailanthus altissima & Simaroubaceae & 2,6-Dimethoxy-p-benzoquinone \\
\hline & 5 & Dalbergia odorifera & Papilionaceae & Claussequinone \\
\hline & 6 & Acanthopanax senticosus & Araliaceae & 2,6-Dimethoxybenzoquinone \\
\hline \multirow{6}{*}{ Naphthoquinones } & 1 & Lithospermum erythrorhizon & Boraginaceae & $\begin{array}{l}\beta, \beta \text {-Dimethylacrylshikonin, deoxyshikonin, acetylshikonin, } \\
\text { L-shikonin }\end{array}$ \\
\hline & 2 & Catalpa & Bignoniaceae & Lapachol \\
\hline & 3 & Plumbago zeylanica & Plumbaginaceae & Plumbagin \\
\hline & 4 & Juglans regia & Juglandaceae & Juglone \\
\hline & 5 & Medicago sativa & Leguminosae & Vitamin $\mathrm{K}_{1}$ \\
\hline & 6 & Salvia prionitis Hance & Labiatae & Saprorthoquinone, sapriparaquinone, salvicine \\
\hline \multirow{6}{*}{ Phenanthrenequinones } & 1 & Salvia miltiorrhiza & Labiatae & $\begin{array}{l}\text { Nordanshenquinone, cryptosalvianoquinone, tanshinones I } \\
\text { and IIA }\end{array}$ \\
\hline & 2 & Salvia aerea & Labiatae & Przewaquinone A-F \\
\hline & 3 & Salvia trijuga & Labiatae & Trijuganones A and $\mathrm{B}$, tanshinones I and IIA \\
\hline & 4 & Rosmarinus officinalis & Labiatae & Cryptosalvianoquinone, horminone, taxodione \\
\hline & 5 & Asparagus cochinchinensis & Asparagaceae & Dioscoreanone \\
\hline & 6 & Dendrobium nobile & Orchidaceae & Denbinobin \\
\hline \multirow{15}{*}{ Anthraquinones } & 1 & Rheum palmarum & Polygonaceae & Emodin, physcion, and rhein \\
\hline & 2 & Fallopia multiflora & Polygonaceae & Emodin, physcion, and rhein \\
\hline & 3 & Reynoutria japonica & Polygonaceae & Fallacinolw-O-acetate, emodin \\
\hline & 4 & Morinda officinalis & Rubiaceae & Physcion, rubiadin \\
\hline & 5 & Rubia cordifolia & Rubiaceae & Munjistindimethylether \\
\hline & 6 & Arisaema erubescens & Rubiaceae & Digitoquinone \\
\hline & 7 & Folium Sennae & Leguminosae & Emodin and sennosides A, B, C, and D \\
\hline & 8 & Semen cassiae & Leguminosae & Emodin, chrysophanol, rhein, and physcion \\
\hline & 9 & $\begin{array}{l}\text { Astragalus propinquus } \\
\text { Schischkin }\end{array}$ & Leguminosae & Aloe-emodin, rhein, emodin, chrysophanol, and physcion \\
\hline & 10 & Polygonatum sibiricum & Liliaceae & Polygonaquinone \\
\hline & 11 & Ophiopogon japonicus & Liliaceae & Emodin and chrysophanol \\
\hline & 12 & Aloe vera & Asphodelaceae & Aloe-emodin and aloin \\
\hline & 13 & Tripterygium wilfordii & Celastraceae & 1,8-Dihydroxy-4-hydroxymethyl anthraquinone \\
\hline & 14 & Curcuma longa & Zingiberaceae & 2-Hydroxymethylhydrazine \\
\hline & 15 & Sargentodoxa cuneata & Lardizabalaceae & Chrysophanol \\
\hline
\end{tabular}

not activate apoptosis-related proteins, including caspase-8, caspase-3, apoptosis protease-activating factor-1, and apoptosis-inducing factor (AIF). Therefore, the A549 cells treated with this compound show a cellular pattern related to the death of necrotic cells rather than apoptosis in vitro [17].

Tanshinone IIA, tanshinone I, and cryptotanshinone isolated from Salvia miltiorrhiza have been reported to exert antilung cancer effects [18]. Tanshinone IIA can inhibit A549 cell proliferation, activate the JNK signal transduction, and trigger caspase cascade apoptosis induced by releasing caspase activators, including CytC [19]. Tanshinone I, which is a possible radiation sensitizer in lung cancer treatment, can significantly inhibit cell proliferation and clone formation so as to promote the radiosensitivity of radioresistant lung cancer cells. Additionally, it can downregulate phosphoribosyl pyrophosphate aminotransferase (PPAT) expression in lung cells, H358-IR and H157-IR. Molecular docking results suggest that tanshinone I is docked well into the binding site of PPAT; therefore, this compound may serve as a novel PPAT inhibitor [20]. Cryptotanshinone can induce immunological antitumor responses; it inhibits proliferation via upregulating p53, downregulating Cdc2 and cyclin B1, and blocking cell cycle at G2/M phase in Lewis lung carcinoma (LLC) cells. Meanwhile, cryptotanshinone promotes mouse and human dendritic cell maturation by upregulating MHC and 
TABLE 2: Common antilung cancer quinonoids.

\begin{tabular}{lccc}
\hline No. & Compounds & Type & Plant sources \\
\hline 1 & Embelin & Benzoquinones & Embelia laeta, Ardisia oxyphylla \\
2 & Thymoquinone & Benzoquinones & Nigella damascena \\
3 & Plumbagin & Naphthoquinones & Plumbago zeylanica \\
4 & B, -Dimethylacryloylshikonin & Naphthoquinones & Lithospermum erythrorhizon \\
5 & Juglone & Naphthoquinones & Juglans regia \\
6 & Salvicine & Naphthoquinones & Salvia prionitis Hance \\
7 & Acetylshikonin & Naphthoquinones & Lithospermum erythrorhizon \\
8 & Alkannin (SYUNZ-16) & Naphthoquinones & Lithospermum erythrorhizon \\
9 & Emodin & Anthraquinones & Rheum palmarum, Fallopia multiflora, Cassia senna \\
10 & Chrysophanol & Anthraquinones & Rheum palmarum, Sargentodoxa cuneata \\
11 & Rhein & Anthraquinones & Rheum palmarum, Fallopia multiflora \\
12 & Aloin & Anthraquinones & Aloe vera \\
13 & Aloe-emodin & Anthraquinones & Aloe vera, Semen cassiae \\
14 & Tanshinone IIA & Phenanthrenequinones & Salvia miltiorrhiza, Salvia trijuga \\
15 & Cryptotanshinone & Phenanthrenequinones & Salvia miltiorrhiza, Rosmarinus officinalis \\
16 & Dioscoreanone & Phenanthrenequinones & Asparagus cochinchinensis \\
17 & Denbinobin & Phenanthrenequinones & Dendrobium nobile \\
18 & Przewalanshinguinone A & Phenanthrenequinones & Salvia aerea \\
\hline
\end{tabular}

costimulatory molecules, as well as by the production of TNF- $\alpha$, IL- 12 p70, and IL-1 $\beta$ [21]. Pretreatment with cryptotanshinone not only can inhibit the basal levels of IGF-1R and Akt phosphorylation but also can block IGF-1-induced phosphorylation of IGF-1R and Akt. This finding indicates that cryptotanshinone suppresses lung cancer cell proliferation and migration by inhibiting the PI3K/Akt pathway mediated by IGF-1R [22].

The STAT3 signal transduction pathway plays a key role in the biology of NSCLC. Yang et al. [23] found that rhein, a lipophilic anthraquinone, might exert its antilung cancer effect by inhibition of STAT3. Rhein can markedly reduce viabilities and induce apoptosis in human lung cancer A549, PC9, and H460 cells. Rhein can upregulate the proapoptotic protein Bax expression and downregulate the antiapoptotic protein Bcl-2 expression. Furthermore, rhein induces G2/M phase arrest in NSCLC cells and inhibits cycle-related protein expression. It was further found in vivo that rhein could significantly suppress $\mathrm{H} 460$ tumor growth in xenograft models.

Juglone, a naphthoquinone, isolated from Juglans regia is a potential cytotoxic compound against human lung cancer cell lines, and the electron-withdrawing groups at the ortho position of the R moiety of juglone seem to be necessary for the enhancement of its cytotoxic activity [24].

Wan et al. [25] found that aloin may induce A549 cell apoptosis via the ROS-MAPK pathway and $\mathrm{p} 53$ phosphorylation. Aloin can disrupt the MMP, elevate cytosolic $\mathrm{Ca}^{2+}$ levels, and activate Bak, Bax, p53-upregulated modulator of apoptosis, and phorbol-12-myristate-13-acetate-induced protein 1 . It can also promote $\mathrm{p} 53$ phosphorylation.

Aloe-emodin can significantly induce apoptosis, release nuclear phosphoric acid from nucleus to cytoplasm, increase the size of a nucleoprotein in the cytoplasm and the number of fragments, and increase activated caspase- 3 and PARP shear. It can promote ROS production and activate MAPKs, inactivate the PI3K-Akt pathway, and inhibit cancer cell proliferation [26]. Anoikis induced by aloe-emodin is associated with the expression levels of MAP kinase members [27]. Active oxygen species produced by aloe-emodin in $\mathrm{H} 460$ cells can induce DNA single-strand breaks and decrease the mRNA levels of DNA repair enzymes, such as hMTH1, hOGG1, and DNA damage repair gene depurine/apyrimidine endonuclease mRNA [28]. In lung cancer cell H460, photoactivated aloe-emodin can induce anoikis and morphological changes by acting on the cytoskeleton, promote the expression of PKC, and regulate cytoskeleton-related proteins mediated by PKC [29]. ER stress is accompanied by mitochondrial damage in this process. The expression of ER chaperone molecule HSP70, $150 \mathrm{kDa}$ oxygen-regulated protein, and protein disulfide-isomerase increases. ATP synthase is inhibited. Thus, ATP level decreases in a timedependent manner [30].

Salvicine can induce DNA double-strand breaks and telomere erosion in A549 cells. It can cause telomere binding protein 2 (TRF2) destruction but does not depend on its transcription or proteasome-mediated degradation. On the one hand, TRF2 protects telomeric DNA and genomic DNA. On the other hand, the human anthrax toxin receptor (ATR) and TRF2 regulate each other by inducing DNA damage signal transduction during cancer development. ATR is essential for telomere erosion. Activated ATR increases TRF2 damage induced by salvicine, and reduced TRF2 can enhance ATR function [31]. Salvicine inhibits telomerase activity of human lung adenocarcinoma A549 cells only under high-concentration and short-term irradiation and also suppresses the activity of telomerase more severely than other drugs. In addition, $4 \mathrm{~h}$ exposure to salvicine has no 
effect on the mRNA levels of human telomerase reverse transcriptase (hTERT), human telomerase-associated protein 1 (hTP1), and human telomerase (hTR) in A549 cells [32].

SYUNZ-16 can induce human lung adenocarcinoma cell apoptosis and suppress tumor growth via inhibiting $\mathrm{PKB} / \mathrm{Akt}$ kinase activity and blocking the Akt/FOXO signaling pathway. Treatment of GLC-82 cells with SYUNZ-16 can decrease Akt phosphorylation and increase annexin $\mathrm{V}$ positive cells and cleaved caspase- 3 and PARP fragments. It partially weakens FKHR and FKHRL1 phosphorylation, promotes FKHR accumulation in the nucleus, and upregulates the mRNA levels of Bim and TRADD in tumor cells [33].

Dioscoreanone isolated from Dioscorea membranacea Pierre exhibits antiproliferative and cytotoxic activities in A549 cells. It slows down the rate of cell division and arrests cells at the G2/M stage, resulting in an increase in the sub-G1 apoptotic cell population. Additionally, dioscoreanone can increase the values of the $\mathrm{Bax} / \mathrm{Bcl}-2$ ratio in drug-treated cells, indicating that dioscoreanone induces apoptosis through the mitochondrial signaling pathway [34].

ASK1 is associated with various diseases induced by oxidative stress. A549 cells treated with denbinobin show increases in the activity of ASK1 and the production of ROS, and denbinobin induces JNK activation and c-Jun phosphorylation. Thus, an AP-1-specific DNA-protein complex forms and the expression of Bim increases. Ultimately, denbinobin leads to A549 apoptosis. During apoptosis, denbinobin can induce MMP loss and promote the release of mitochondrial apoptotic factors. In addition, denbinobin induces the inactivation of Akt, and transfection of A549 cells with wild-type-Akt and constitutively active Akt dramatically suppresses the activation of $\mathrm{Bad}$ and cell apoptosis induced by denbinobin $[35,36]$.

Przewaquinone A isolated from the roots of Meriandera benghalensis has strong cytotoxic effect on lung cancer A427 cell lines [37]. Table 3 summarizes the above antilung cancer quinonoids.

3.2. Quinonoids Induce Autophagy. Quinonoids can also induce autophagy-related cell death in lung cancer cells (Table 4). The loss of p53 function, through mutations, is involved in the development of various human cancers. Haque et al. [38] found that emodin treatment can upregulate LC3 expression by blocking p53 aggregation and inducing autophagy in A549 cells, which can dissociate the coaggregation of ATG5 and p53 aggregates and restore p53 function.

Plumbagin exhibits potential proautophagic and proapoptotic effects on human NSCLC cells. It can arrest the cell cycle in the G2/M stage and increase the ROS level in both A549 and H23 cells. A crosstalk occurs between autophagy and apoptosis induced by plumbagin. Plumbagin triggers autophagy by inhibiting the PI3K/Akt/mTOR pathway, and the induction of autophagy enhances plumbagin-induced apoptosis [39].

Cryptotanshinone can induce intracellular ROS generation at a dose- and time-dependent pattern, promote LC3 expression, and induce autophagy. However, autophagy induced by cryptotanshinone can be inhibited by N- acetylcysteine (NAC), JNK siRNA, and SP600125. In A549 xenograft nude mice, cryptotanshinone $\left(10 \mathrm{mg} \cdot \mathrm{kg}^{-1}\right)$ can dramatically inhibit tumor growth, which can be reversed by cotreatment with NAC. These findings show that cryptotanshinone can induce a prodeath autophagy via the activation of the JNK pathway [40].

3.3. Quinonoids Inhibit Angiogenesis and Tumor Metastasis and Invasion. Angiogenesis is a key factor involved in the invasion and metastasis of human lung cancer. Some quinonoids can inhibit angiogenesis and thus prevent lung cancer from progressing.

Emodin can inhibit A549 cell proliferation, migration, and epithelial-mesenchymal transition (EMT) induced by ATP through inhibiting the $\mathrm{P} 2 \mathrm{Y}$ receptor-mediated $\mathrm{Ca}^{2+}$ increase and NF- $\kappa \mathrm{B}$ activation [41]. CXC chemokine receptor 4 (CXCR4) is closely related to the occurrence and development of tumor. Emodin can suppress invasion and migration of A549 cells via downregulating CXCR4 expression; thus, it has the potential to treat metastatic cancers [42].

Recent studies have shown that osteopontin (OPN) can stimulate movement and invasion in A549 cells. However, plumbagin can effectively inhibit OPN-induced ROCK1 expression and the phosphorylation levels of LIM kinase $1 / 2$ and cofilin and reduce OPN-induced FAK and Akt phosphorylation. In vivo studies further demonstrate that plumbagin can suppress lung metastasis [43]. Plumbagin can also suppress the proliferation and invasion of human large-cell lung cancer cell lines by regulating the IL-6/STAT3 pathway [44].

Thymoquinone is an edible redox-active quinone. It can suppress the proliferation, migration, and invasion of A549 cells via the ERK1/2 signaling pathway. The therapeutic potential of thymoquinone as an anti-invasive and antimetastatic drug in human NSCLC treatment has been explored [45].

As indicated by molecular docking analyses, tanshinone IIA can bind well at the VEGFR2 kinase site to form $\mathrm{H}$ bond with Cys917 in a unique mode and form $\pi-\pi$ stacking interaction with Val828. This finding indicates that tanshinone IIA can inhibit angiogenesis by targeting VEGF/VEGFR2 protein kinase domains [46].

Three naphthoquinone derivatives (shikonin, acetylshikonin, and isobutyl shikonin) effectively inhibit the migration of HUVECs treated with VEGF. Shikonin has a specific inhibitory effect on the generation of VEGF. These three derivatives can downregulate uPA expression but do not inhibit the expression of its receptor uPAR. Shikonin can also significantly suppress the growth of LLC tumors in vivo, while the effect of its derivatives is relatively mild. The findings show that shikonin and its derivatives have antiangiogenic and antitumorigenic effects [47].

It is well known that IGF-1R activity is closely related to angiogenesis and tumor growth. Tsai et al. [48] found that denbinobin could suppress the growth and microvessel formation of A549 cells by blocking the IGF-1R pathway. It can selectively inhibit IGF-1-mediated proliferation and tube formation of HUVECs but not affect the role of EGF, VEGF, and bFGF. Therefore, denbinobin may be a new type of the 
TABLE 3: Effect of quinonoids on inhibiting proliferation and inducing apoptosis or necrosis of lung cancer.

\begin{tabular}{|c|c|c|c|c|c|}
\hline Quinonoids & $\begin{array}{l}\text { Cell lines or animal } \\
\text { models }\end{array}$ & Doses & Targets & Pharmacodynamic effects & Ref. \\
\hline Embelin & A549 cells & $2.5 \sim 25 \mu \mathrm{M}$ & p38, JNK, ERK1/2 & Induce apoptosis & {$[6]$} \\
\hline \multirow{8}{*}{ Emodin } & A549 cells & $18.5 \sim 129.5 \mu \mathrm{M}$ & FasL, c-Myc & $\begin{array}{l}\text { Inhibit cell growth and } \\
\text { induce apoptosis }\end{array}$ & {$[7]$} \\
\hline & Anip973 cells & $10 \sim 60 \mu \mathrm{M}$ & Caspase-3 & $\begin{array}{l}\text { Induce apoptosis, arrest cell } \\
\text { cycle }\end{array}$ & {$[8]$} \\
\hline & $\begin{array}{l}\text { A549 and H1299 } \\
\text { cells } \\
\text { A549 xenograft } \\
\text { nude mice }\end{array}$ & $\begin{array}{c}20 \sim 80 \mu \mathrm{M} \\
50 \mathrm{mg} / \mathrm{kg}\end{array}$ & TRIB3, NF- $\kappa \mathrm{B}$ & $\begin{array}{l}\text { Induce apoptosis, suppress } \\
\text { tumor growth }\end{array}$ & [9] \\
\hline & A549 cells & $50 \mu \mathrm{M}$ & p53, Bax, CytC, caspase-3 & Induce apoptosis & [10] \\
\hline & $\begin{array}{l}\text { A549 and H1975 } \\
\text { cells } \\
\text { A549 xenograft } \\
\text { nude mice }\end{array}$ & $\begin{array}{c}50 \mu \mathrm{M} \\
25 \sim 50 \mathrm{mg} / \mathrm{kg}\end{array}$ & $\begin{array}{l}\mathrm{AMPK} \alpha, \mathrm{ERK} 1 / 2, \mathrm{PPAR} \gamma \\
\text { IGFBP1, Sp1 }\end{array}$ & $\begin{array}{l}\text { Arrest cell cycle, inhibit } \\
\text { tumor growth }\end{array}$ & [11] \\
\hline & $\begin{array}{l}\text { A549 and SK-MES- } \\
1 \text { cells }\end{array}$ & 70 and $40 \mu \mathrm{M}$ & ERCC1, Rad51 & Inhibit proliferation & {$[12]$} \\
\hline & $\begin{array}{l}\mathrm{H} 1650, \mathrm{~A} 549, \mathrm{H} 520 \\
\text { and H1703 cells }\end{array}$ & $10 \sim 100 \mu \mathrm{M}$ & ERCC1, Rad51, MKK1/2, ERK1/2 & Induce cytotoxicity & [13] \\
\hline & H460 cells & $1 \sim 50 \mu \mathrm{M}$ & RXR & $\begin{array}{l}\text { Inhibit proliferation, induce } \\
\text { apoptosis }\end{array}$ & {$[14]$} \\
\hline Plumbagin & $\begin{array}{l}\text { A549, H292, H460 } \\
\text { cells }\end{array}$ & $3 \sim 18 \mu \mathrm{M}$ & $\begin{array}{c}\text { NK- } \kappa \text { B, caspase- } 9 \text {, caspase- } 3 \text {, Bcl- } \\
2 \text {, Bax, Bak, CytC, I } \kappa \text { B }\end{array}$ & $\begin{array}{l}\text { Inhibit proliferation, induce } \\
\text { apoptosis }\end{array}$ & [15] \\
\hline$\beta, \beta$-Dimethylacrylshikonin & A549 cells & $7.5 \sim 15 \mu \mathrm{M}$ & $\begin{array}{c}\text { p38, caspase-9, caspase- } 8 \text {, caspase- } \\
\text { 3, PARP, CytC }\end{array}$ & $\begin{array}{l}\text { Inhibit proliferation, induce } \\
\text { apoptosis }\end{array}$ & {$[16]$} \\
\hline Chrysophanol & A549 cells & $1 \sim 100 \mu \mathrm{M}$ & CytC & $\begin{array}{l}\text { Inhibit proliferation, induce } \\
\text { necrosis }\end{array}$ & [17] \\
\hline \multirow[t]{2}{*}{ Tanshinone IIA } & $\begin{array}{l}\text { H1299, A549, } \\
\text { SPCA-1, HCC } 827, \\
\text { and BEAS-2B cells }\end{array}$ & $2 \sim 4 \mu \mathrm{M}$ & miR-32, AURKA & $\begin{array}{l}\text { Inhibit proliferation, } \\
\text { promote apoptosis, and } \\
\text { block cell cycle }\end{array}$ & [18] \\
\hline & A549 cells & $2.5 \sim 40 \mu \mathrm{M}$ & $\begin{array}{c}\text { JNK, caspase- } 9 \text {, caspase- } 3 \text {, Bax, } \\
\text { CytC }\end{array}$ & Induce apoptosis & [19] \\
\hline Tanshinone I & $\begin{array}{l}\text { H358-IR and } \\
\text { H157-IR cells }\end{array}$ & $10 \mu \mathrm{M}$ & PPAT & $\begin{array}{l}\text { Inhibit proliferation and } \\
\text { clone formation }\end{array}$ & [20] \\
\hline \multirow[b]{2}{*}{ Cryptotanshinone } & LLC cells & $1.1 \sim 67.5 \mu \mathrm{M}$ & p53, cyclin B1, and Cdc2 & Inhibit proliferation & {$[21]$} \\
\hline & $\begin{array}{l}\text { A549 and H1299 } \\
\text { cells }\end{array}$ & $1 \sim 50 \mu \mathrm{M}$ & IGF-1R, Akt & $\begin{array}{l}\text { Inhibit IGF-1-induced } \\
\text { proliferation }\end{array}$ & [22] \\
\hline Rhein & $\begin{array}{l}\text { PC9, H460, and } \\
\text { A549 cells } \\
\text { H460 xenograft } \\
\text { nude mice } \\
\end{array}$ & $\begin{array}{c}30 \sim 100 \mu \mathrm{M} \\
60 \sim 100 \mathrm{mg} / \mathrm{kg}\end{array}$ & $\begin{array}{l}\text { p-STAT3, Bcl-2, Bax, MDM2, } \\
\text { Cdc2, p53, and cyclin B1 }\end{array}$ & $\begin{array}{l}\text { Induce apoptosis, block cell } \\
\text { cycle, and suppress tumor } \\
\text { growth }\end{array}$ & [23] \\
\hline Juglone & $\begin{array}{l}\text { NCI-H322 and } \\
\text { A549 cells }\end{array}$ & $2 \sim 50 \mu \mathrm{M}$ & - & Induce cytotoxicity & {$[24]$} \\
\hline Aloin & A549 cells & $100 \sim 400 \mu \mathrm{M}$ & p53, c-Jun/p38, Bcl-2 & $\begin{array}{l}\text { Inhibit cell proliferation and } \\
\text { induce apoptosis }\end{array}$ & [25] \\
\hline Aloe-emodin & $\begin{array}{l}\text { H520, H226, } \\
\text { SK-MES-1, and } \\
\text { H1299 cells } \\
\text { H520 xenograft } \\
\text { nude mice }\end{array}$ & $\begin{array}{c}2.5 \sim 40 \mu \mathrm{M} \\
20 \mathrm{mg} / \mathrm{kg}\end{array}$ & $\begin{array}{l}\text { Caspase-3, PARP, caspase- } 8 \text {, } \\
\text { caspase- } 9 \text {, MAPKs, PI3K/Akt }\end{array}$ & $\begin{array}{l}\text { Inhibit cell proliferation, } \\
\text { promote apoptosis, and } \\
\text { suppress tumor growth }\end{array}$ & [26] \\
\hline
\end{tabular}


TABLE 3: Continued.

\begin{tabular}{|c|c|c|c|c|c|}
\hline Quinonoids & $\begin{array}{l}\text { Cell lines or animal } \\
\text { models }\end{array}$ & Doses & Targets & Pharmacodynamic effects & Ref. \\
\hline & H460 cells & $10 \sim 40 \mu \mathrm{M}$ & $\begin{array}{l}\text { Caspase- } 3 \text {, caspase- } 7 \text {, caspase- } 8 \text {, } \\
\text { and caspase- } 9, \text { MAPK, } \alpha \text {-actinin, } \\
\text { HSP } 27, \text { p38, Bax/Bcl-2 }\end{array}$ & Induce anoikis & [27] \\
\hline & H460 cells & $40 \mu \mathrm{M}$ & hMTH1, hOGG1, APE & $\begin{array}{l}\text { Induce DNA damage and } \\
\text { apoptosis }\end{array}$ & [28] \\
\hline & H460 cells & $20 \mu \mathrm{M}$ & PKC, RHO, p38, HSP27, FAK & Induce cell death & [29] \\
\hline & H460 cells & $40 \mu \mathrm{M}$ & HSP60, HSP70 & Induce cell death & [30] \\
\hline \multirow[t]{2}{*}{ Salvicine } & A549 cells & $25 \sim 100 \mu \mathrm{M}$ & $\begin{array}{c}\text { TRF2, } \gamma \text {-H2AX, ATM, ATR, } \\
\text { p-p53, Hif } 1 \alpha\end{array}$ & $\begin{array}{l}\text { Initiate telomere erosion } \\
\text { and DNA double-strand } \\
\text { breaks }\end{array}$ & {$[31]$} \\
\hline & A549 cells & $6.25 \sim 50 \mu \mathrm{M}$ & hTERT, hTP1, hTR & $\begin{array}{l}\text { Inhibit the telomerase } \\
\text { activity }\end{array}$ & {$[32]$} \\
\hline Alkannin & GLC-82 & $0.18 \sim 21.8 \mu \mathrm{M}$ & $\begin{array}{c}\text { Caspase-3, PARP, p-GSK } 3 \alpha / \beta \text {, } \\
\text { p-Akt, p-FKHRL1, TRADD, Bim }\end{array}$ & $\begin{array}{l}\text { Inhibit cell proliferation and } \\
\text { induce apoptosis }\end{array}$ & [33] \\
\hline Dioscoreanone & A549 cells & $0.35 \sim 35 \mu \mathrm{M}$ & Bax/Bcl-2, caspase-3 & Induce apoptosis & [34] \\
\hline \multirow{2}{*}{ Denbinobin } & A549 cells & $20 \mu \mathrm{M}$ & ASK1, JNK, AP-1, c-Jun, Bim & Induce apoptosis & [35] \\
\hline & A549 cells & $1 \sim 20 \mu \mathrm{M}$ & CytC, Smac, AIF, Bad, Bcl-xL, Akt & Induce apoptosis & [36] \\
\hline Przewaquinone A & A427 cells & - & - & Induce cytotoxicity & [37] \\
\hline
\end{tabular}

TABLE 4: Effect of quinonoids in inducing lung cancer autophagy.

\begin{tabular}{|c|c|c|c|c|c|}
\hline Quinonoids & $\begin{array}{c}\text { Cell lines or animal } \\
\text { models }\end{array}$ & Doses & Targets & Pharmacodynamic effects & Ref. \\
\hline Emodin & A549 cells & $10 \sim 20 \mu \mathrm{M}$ & ATG5, p53, LC3 & Induce autophagic cell death & [38] \\
\hline Plumbagin & $\begin{array}{l}\text { A549 cells, } \\
\text { H23 cells }\end{array}$ & $0.5 \sim 10 \mu \mathrm{M}$ & $\begin{array}{l}\text { PI3K, Akt, p38, mTOR, } \\
\text { LC3I, LC3II, Beclin1 }\end{array}$ & $\begin{array}{l}\text { Induce apoptotic and autophagic cell death and } \\
\text { block cell cycle }\end{array}$ & [39] \\
\hline Cryptotanshinone & $\begin{array}{l}\text { A549 cells, } \\
\text { A549 xenograft } \\
\text { nude mice }\end{array}$ & $\begin{array}{l}1.25 \sim 40 \mu \mathrm{M} \\
10 \mathrm{mg} / \mathrm{kg}\end{array}$ & LC3I, p-JNK, LC3II & $\begin{array}{l}\text { Induce autophagic cell death and inhibit tumor } \\
\text { growth }\end{array}$ & {$[40]$} \\
\hline
\end{tabular}

IGF-1R kinase inhibitor, which has therapeutic potential for angiogenesis-related diseases, such as lung cancer.

Recent reports suggest that the basic fibroblast growth factor (bFGF) is also associated with angiogenesis in many malignant tumors. Salvicine, which is a naphthoquinone derivative, can effectively inhibit the migration and tube formation of HMECs. Moreover, it can significantly reduce the expression of bFGF mRNA, whereas the expression of VEGF mRNA remains unchanged in A549 cells. Salvicine possibly exerts potential antiangiogenic effect by inhibiting the proliferation, migration, and angiogenesis, which is related to bFGF expression in tumor cells [49]. The effects of quinonoids on the inhibition of angiogenesis, tumor migration, and invasion are summarized in Table 5.

\subsection{Quinonoids Enhance the Antilung Cancer Effect of Other} Drugs. The multidrug resistance (MDR) of lung cancer cells to chemotherapeutic drugs is a major cause in the unsatisfactory effect of chemotherapeutic drugs. Traditional Chinese medicine (TCM) monomers can reverse MDR in lung cancer in many ways and multiple levels, and this feature is a manifestation of the advantages of natural monomers in high-efficiency, low-toxicity, and multitarget antilung cancer treatment [50]. Quinonoids are used in this field. Some quinonoids can attenuate toxicity and increase efficiency and reverse multidrug resistance to lung cancer.

Embelin can enhance TNF-related apoptosis-inducing ligand- (TRAIL-) induced apoptosis in A549 cells. The synergistic antitumor effect of embelin-TRAIL cotreatment might be related to regulation of multiple factors in the TRAIL receptor-mediated apoptotic pathway, such as survivin, Bcl2, TRAILR2, c-FLIP, and XIAP [51]. High XIAP expression plays an important role in regulating cisplatin resistance in H460 lung cancer cells. Embelin (XIAP inhibitor) or siRNA can increase the activation of caspase- 3 by blocking XIAP activity and promote the death of cisplatin-induced H460 cells [52].

Core EMT factors Snail, Slug, and Twist promote cell proliferation, metastasis, and invasion and inhibit the apoptosis of H69AR cells. Compared to doxorubicin- (Dox-) 
TABLE 5: Effect of quinonoids in inhibiting angiogenesis, tumor migration, and invasion.

\begin{tabular}{|c|c|c|c|c|c|}
\hline Quinonoids & $\begin{array}{c}\text { Cell lines or } \\
\text { animal models }\end{array}$ & Doses & Targets & Pharmacodynamic effects & Ref. \\
\hline \multirow{2}{*}{ Emodin } & A549 cells & $0.1 \sim 10 \mu \mathrm{M}$ & $\mathrm{P} 2 \mathrm{Y}$ receptors, NF- $\kappa \mathrm{B}$ & Inhibit cell proliferation, migration, and EMT & [41] \\
\hline & A549 cells & $50 \sim 100 \mu \mathrm{M}$ & CXCR4, CXCL12, HER2, NF- $\kappa$ B & Inhibit cell migration and invasion & [42] \\
\hline \multirow[t]{2}{*}{ Plumbagin } & $\begin{array}{l}\text { A549 cells } \\
\text { A549 } \\
\text { xenograft } \\
\text { nude mice }\end{array}$ & $\begin{array}{l}1 \sim 8 \mu \mathrm{M} \\
5 \mathrm{mg} / \mathrm{kg}\end{array}$ & $\begin{array}{l}\text { FAK, Akt, ROCK1, LIMK1/2, } \\
\text { cofilin }\end{array}$ & $\begin{array}{l}\text { Reduce OPN-induced invasion, suppress lung } \\
\text { metastasis }\end{array}$ & [43] \\
\hline & $\begin{array}{l}\text { L9981 and } \\
\text { NL9980 cells }\end{array}$ & $3 \sim 12 \mu \mathrm{M}$ & IL-6, STAT3 & Inhibit cell proliferation and invasion & [44] \\
\hline Thymoquinone & A549 cells & $5 \sim 160 \mu \mathrm{M}$ & $\begin{array}{l}\text { ERK1/2, PCNA, cyclin D1, } \\
\text { MMP2, and MMP9 }\end{array}$ & $\begin{array}{l}\text { Inhibit cell proliferation, migration, } \\
\text { and invasion }\end{array}$ & [45] \\
\hline Tanshinone IIA & A549 cells & $2.5 \sim 80 \mu \mathrm{M}$ & VEGF, VEGFR2 & $\begin{array}{l}\text { Inhibit proliferation by blocking cell cycle and } \\
\text { inducing apoptosis and inhibit angiogenesis }\end{array}$ & [46] \\
\hline Acetylshikonin & $\begin{array}{c}\text { A549 cells } \\
\text { LLC-bearing } \\
\text { mice }\end{array}$ & $\begin{array}{l}5 \sim 20 \mu \mathrm{M} \\
2 \mathrm{mg} / \mathrm{kg}\end{array}$ & uPA & Inhibit angiogenesis and tumorigenesis & [47] \\
\hline Denbinobin & $\begin{array}{c}\text { A549 cells } \\
\text { A549 } \\
\text { xenograft mice }\end{array}$ & $\begin{array}{l}0.1 \sim 10 \mu \mathrm{M} \\
25 \mathrm{mg} / \mathrm{kg}\end{array}$ & $\begin{array}{l}\text { IGF-1R, ERK, Akt, mTOR, } \\
\text { p70S6K, 4EBP, and cyclin D1 }\end{array}$ & $\begin{array}{l}\text { Inhibit IGF-1-induced angiogenesis in } \\
\text { vitro and in vivo }\end{array}$ & [48] \\
\hline Salvicine & A549 cells & $0.625 \sim 200 \mu \mathrm{M}$ & bFGF & Inhibit angiogenesis & [49] \\
\hline
\end{tabular}

sensitive H69 cells, H69AR can induce Snail, Slug, and Twist expression, whereas emodin combined with Dox can effectively inhibit their expression. The results indicate that emodin can reverse H69AR cell resistance to Dox by inhibiting cell proliferation, cell migration, cell invasion, and EMT [53]. Rad51 plays a critical role in homologous recombination and is highly expressed in cancers tolerant to chemotherapy or radiation. Emodin can enhance mitomycin C- (MMC-) induced cytotoxic effects through reducing the levels of Rad51 and ERK1/2 phosphorylation. By contrast, Rad51 overexpression can protect H1703 or A549 cells from synergistic cytotoxicity mediated by MMC and emodin [54].

Emodin can significantly enhance paclitaxel-elicited apoptosis of A549 cells by upregulating the Bax and active caspase-3 expression and downregulating p-Akt, p-ERK, and Bcl-2 expression. Furthermore, emodin can effectively enhance the anticancer activity of paclitaxel on the A549 xenograft model with no obvious side effect in vivo [55].

Tanshinone IIA can increase TRAIL-mediated apoptosis by upregulating DR5 and downregulating survivin. The processes are induced by selectively activating the PERK/ATF4 signaling pathway and inhibiting STAT3, respectively. These features suggest that tanshinone IIA combined with TRAIL is a novel strategy for the treatment of NSCLC [56]. Tanshinone IIA combined with cyclophosphamide can downregulate $\mathrm{Bcl}-2$, upregulate Bax, suppress neovascularization of lung cancer, and boost the immune functions [57]. Tanshinone IIA and Dox can synergistically induce apoptosis, inhibit migration of A549 cells, and block cell cycle in the S and G2 stages. Compared with the single drug use, a combined treatment can further downregulate the protein levels of VEGFR2, VEGF, caspase-3, p-PI3K, p-Akt, and Bcl-2. The results of molecular docking show that tanshinone IIA can be bound into the active pockets of all the proteins tested compared with Dox [58]. Tanshinone IIA combined with cisplatin exerts a synergistic inhibitory effect on A549 and PC9 cells. A combination treatment induces apoptosis, impairs invasion and migration, and blocks the cell cycle at the S stage in NSCLC cells. Molecular docking and KEGG analysis show that tanshinone IIA may mainly affect the PI3K/Akt pathway [59].

The combination of rhein lysinate and paclitaxel can significantly inhibit H460 and A549 cell proliferation. Rhein lysinate enhances paclitaxel-elicited cytotoxicity via downregulating the activity of ERK and upregulating the expression of cleaved PARP and caspase-3 [60].

The expressions of endogenous Nrf2 and its target genes, including HO-1, MRP1, GCLC, GCLM, and NQO1, are much higher in cisplatin-resistant A549 cells than in A549 cells. Cryptotanshinone combined with cisplatin can make cisplatin-resistant cells sensitive to cisplatin, leading to cell death and apoptosis, whereas the reversal effect can be abolished by knockdown of Nrf2. Notably, cryptotanshinone can significantly diminish the expression of Nrf2, thus reducing the expression levels of Nrf2 target genes. Therefore, cryptotanshinone may develop into a novel anticancer chemotherapy sensitizer by inhibiting the Nrf2 pathway [61]. Cryptotanshinone can promote TRAIL-mediated apoptosis by upregulating DR5, which can convert TRAIL-resistant A549 cells into sensitive ones. The knockdown of DR5 abolishes the enhanced effect of cryptotanshinone on TRAIL response. The induction of DR5 by cryptotanshinone is dependent on CCAAT/CHOP, not p53. 
TABLE 6: Effect of quinonoids in enhancing antilung cancer effect of other drugs.

\begin{tabular}{|c|c|c|c|c|c|}
\hline Quinonoids & $\begin{array}{c}\text { Cell lines or animal } \\
\text { models }\end{array}$ & Doses & Targets & Pharmacodynamic effects & Ref. \\
\hline \multirow[t]{2}{*}{ Embelin } & A549 cells & $6.25 \sim 100 \mu \mathrm{M}$ & $\begin{array}{l}\text { TRAILR2, XIAP, survivin, } \\
\text { Bcl-2, c-FLIP }\end{array}$ & Enhance TRAIL-induced apoptosis & [51] \\
\hline & H460 cells & $25 \mu \mathrm{M}$ & XIAP, caspase-3 & Enhance cisplatin-induced apoptosis & [52] \\
\hline \multirow{3}{*}{ Emodin } & H69AR cells & $1 \sim 50 \mu \mathrm{M}$ & Twist, Snail, Slug, NF- $\kappa$ B & $\begin{array}{l}\text { Reverse the resistance of H69AR } \\
\text { cells to Dox }\end{array}$ & [53] \\
\hline & $\begin{array}{l}\text { H1703 and A549 } \\
\text { cells }\end{array}$ & $60 \sim 200 \mu \mathrm{M}$ & Rad51, ERK1/2 & Enhance MMC-induced cytotoxicity & [54] \\
\hline & $\begin{array}{l}\text { A549 cells } \\
\text { A549 xenograft } \\
\text { nude mice }\end{array}$ & $\begin{array}{l}5 \sim 40 \mu \mathrm{M} \\
50 \mathrm{mg} / \mathrm{kg}\end{array}$ & $\begin{array}{l}\text { Bax, Bcl-2, caspase-3, p-Akt, } \\
\text { and ERK }\end{array}$ & Enhance antitumor effect of paclitaxel & [55] \\
\hline \multirow{4}{*}{ Tanshinone IIA } & $\begin{array}{l}\text { A549, H596, H1299, } \\
\text { Calu-1, and H460 } \\
\text { cells }\end{array}$ & $1 \sim 60 \mu \mathrm{M}$ & $\begin{array}{l}\text { TRAIL, DR5, STAT3, } \\
\text { PERK/ATF4, survivin }\end{array}$ & Enhance TRAIL-induced apoptosis & [56] \\
\hline & LLC-bearing mice & $15 \mathrm{mg} / \mathrm{kg}$ & Bax, Bcl-2 & $\begin{array}{l}\text { Combine with cyclophosphamide to inhibit } \\
\text { neovascularization and enhance immune } \\
\text { function }\end{array}$ & [57] \\
\hline & A549 and PC9 cells & $5 \sim 80 \mu \mathrm{M}$ & $\begin{array}{l}\text { Cleaved caspase-3, Bax, } \\
\text { VEGF, VEGFR2, p-PI3K, } \\
\text { p-Akt, Bcl-2 }\end{array}$ & $\begin{array}{l}\text { Improve the sensitivity of Dox to } \\
\text { NSCLC cells }\end{array}$ & [58] \\
\hline & $\begin{array}{l}\text { A549, PC9, H1299, } \\
\text { and SPA-A1 cells } \\
\text { A549 xenograft } \\
\text { nude mice }\end{array}$ & $\begin{array}{c}1.25 \sim 40 \mu \mathrm{M} \\
7.5 \sim 15 \mathrm{mg} / \mathrm{kg}\end{array}$ & $\begin{array}{l}\text { Bax, cleaved caspase- } 3, \mathrm{Bcl}-2, \\
\text { caspase- } 3, \mathrm{p}-\mathrm{Akt} \text {, and } \mathrm{p}-\mathrm{PI} 3 \mathrm{~K}\end{array}$ & $\begin{array}{l}\text { Combination with cisplatin synergistically } \\
\text { inhibits NSCLC in vitro and in vivo }\end{array}$ & [59] \\
\hline Rhein & $\begin{array}{l}\text { H460 and A549 } \\
\text { cells }\end{array}$ & $100 \mu \mathrm{M}$ & $\begin{array}{l}\text { Bcl-2, NF- } \kappa \text { B, PARP, ERK, } \\
\text { caspase-3 }\end{array}$ & $\begin{array}{l}\text { Enhance the inhibitory effect of paclitaxel } \\
\text { on cell proliferation }\end{array}$ & {$[60]$} \\
\hline \multirow[t]{2}{*}{ Cryptotanshinone } & $\begin{array}{c}\text { A549 and } \\
\text { A549/DDP cells }\end{array}$ & $2.5 \sim 10 \mu \mathrm{M}$ & $\begin{array}{l}\text { Nrf2, GCLC, GCLM, HO-1, } \\
\text { NQO1, MRP1, MAPKs, Akt, } \\
\text { STAT3 }\end{array}$ & $\begin{array}{l}\text { Restore the sensibility of A549/DDP cells } \\
\text { towards cisplatin }\end{array}$ & [61] \\
\hline & A549 cells & $20 \mu \mathrm{M}$ & CHOP, DR5 & $\begin{array}{l}\text { Restore TRAIL sensitivity in } \\
\text { TRAIL-resistant cancer cells }\end{array}$ & [62] \\
\hline
\end{tabular}

The CHOP knockdown abolishes cryptotanshinonemediated DR5 expression and the enhancement of TRAILinduced cell death [62]. The effects of quinonoids in enhancing the antilung cancer effects of other drugs are summarized in Table 6.

\section{Discussion}

Different quinonoids with similar structures belong to a large category, but they have different anticancer effects. Targets involve the multiple pathways of cancer progression, with different emphases on inducing lung cancer cell apoptosis, suppressing proliferation and metastasis, and enhancing the efficacy of anticancer drugs. Thus, quinonoids have wide application prospects. Recently, plentiful research focused on anti-inflammatory, antibacterial, and antioxidative effects of quinonoids. However, with the discovery of their antitumor effects, researchers have started to pay considerable attention to the close relationship between the two effects. Inflammatory stimulation can induce and promote cancers. Intervention in the inflammatory microenvironment of tumors can reshape immunity, enhance the killing of tumor cells, and inhibit tumors. For example, emodin can regulate a series of inflammatory cytokines, such as TNF- $\alpha$, thereby reversing the immunosuppressive rates of tumor microenvironments and promoting tumor cell apoptosis [63]. The continuous activation of the $\mathrm{NF}-\kappa \mathrm{B}$ pathway can increase antiapoptotic gene $\mathrm{Bcl}-2$ expression, upregulate expression of proliferation-related proteins CDK1 and CDK2, and promote cell cycle, thus promoting cancer cell proliferation. Additionally, the process can lead to the upregulation of MMP expression and degradation of the extracellular matrix, thus facilitating the local infiltration of cancer cells [64-66]. The NF- $\kappa \mathrm{B}$ pathway activation can also upregulate angiogenesis-related factor expression, such as VEGF, and promote the metastasis and invasion of cancer $[67,68]$. The Nrf2 pathway can generate detoxification and antioxidant effects [69]. The regulation of these pathways by quinonoids may be the main mechanism of their antilung cancer effects. Previous studies have demonstrated that embelin, rhein, and emodin can suppress the activity of the NF- $\kappa \mathrm{B}$-mediated inflammatory pathway, and cryptotanshinone can play an anticancer role by activating the Nrf2 pathway. 
Most of the TCMs derived from these quinonoids have purgative and anticoagulant effects. Particularly, anthraquinones are widely distributed in purgative drugs. For example, Rheum palmarum, Aloe vera, Folium Sennae, and Polygonum bistorta contain a large number of anthraquinones. These drugs may regulate lung function by acting on the intestinal microenvironment.

Quinonoids are extensively distributed in the plant kingdom and possess a wide spectrum of pharmacological properties. However, recent studies on safety of quinonoids have found that some quinonoids can cause toxicity to the digestive system, urinary system, reproductive system, and immune system; the degree of toxicity mainly depends on dose and exposure time [70-73]. Many reports showed that aloe-emodin exerted hepatotoxicity and nephrotoxicity by inducing apoptosis in the Fas death, mitochondrial, and ER stress-triggered signaling pathway [70, 71]. In addition, emodin could also lead to reproductive toxicity, particularly in high doses and/or long-term use. In male reproductive organs/tissues, the toxicity study of emodin indicated that it has testicular toxicity because of the disruption of the expression of testicular genes. Therefore, long-term administration of high doses of anthraquinone extracts should be avoided altogether during pregnancy [72]. The investigations of potential genotoxicity of plumbagin demonstrated that it can induce significant DNA damage in a dosedependent manner [74], while the evaluation of cytotoxic properties of plumbagin on SKMEL 28 melanoma cell lines and human lymphocytes showed that a very low concentration of plumbagin is sufficient to induce cytotoxic effect on normal cells [73].

Furthermore, some quinonoids are also known to have poor intestinal absorption, short elimination half-life, and low bioavailability in vivo [75], which limit their clinical application further. Traditional drug delivery systems would not be the best method of application of these quinonoids. Therefore, further research studies are needed to improve the bioavailability of quinonoids, reduce toxicity, and enhance their efficacy. Zhou et al. [76] developed a novel hydrogel-based drug delivery system for the delivery of rhein. This rhein-chitosan hydrogel exhibited superior characteristics including sustained release and low toxicity. Aithal et al. [77] compared the pharmacokinetic, biodistribution, pharmacodynamic, and toxicity profiles of free juglone with a sterically stabilized liposomal form. The results showed that sterically stabilized liposomes (SSLs) of juglone exhibited enhanced anticancer activity in vitro and in vivo with reduced toxicity profiles. SSLs also significantly improved the pharmacokinetic and biodistribution attributes of juglone resulting in enhanced plasma half-life and higher tumor accumulation in vivo. Zhang et al. [78] investigated the pharmacokinetic characteristics of rhubarb anthraquinones in rats after being orally administered with rhubarb and rhubarb total free anthraquinone oral colon-specific drug delivery granules. The results found that oral colon-specific drug delivery technology made anthraquinone aglycone to colonspecific release after oral administration. This allowed anthraquinones to not only play the corresponding purgative effect but also avoid intestinal absorption and promote excre- tion and thereby greatly reduced the nephrotoxicity of anthraquinones. Thus, further development of quinonoids can be focused on modification of pharmaceutical formulation to improve pharmacokinetic properties. In addition, a dose-ranging study in animal models should be performed to obtain information on the safety window of effective and toxic doses for extrapolation to humans.

\section{Conflicts of Interest}

The authors declare that there is no conflict of interests regarding the publication of this paper.

\section{Acknowledgments}

This work is financially supported by the Zhejiang Natural Science Foundation (Nos. LY19H280012 and LQ16H200003), National Natural Science Foundation of China (No. 81603368), Zhejiang Disciplinary Construction of Laboratory Animal Genetic Engineering (No. 201604), and Key Laboratory of Neuropsychiatric Drug Research of Zhejiang Province (2019E10021).

\section{References}

[1] L. A. Torre, R. L. Siegel, and A. Jemal, "Lung cancer statistics," Advances in Experimental Medicine and Biology, vol. 893, pp. 1-19, 2016.

[2] A. Bishayee and G. Sethi, "Bioactive natural products in cancer prevention and therapy: progress and promise," Seminars in Cancer Biology, vol. 40-41, pp. 1-3, 2016.

[3] S. J. Wu, T. Zhao, and Y. Q. Qin, Modern component chemistry of Chinese herbal medicine, China Medical Science and Technology Press, Beijing, 2002.

[4] J. Y. Dong, Natural pharmaceutical chemistry, Zhejiang University Press, Hangzhou, 2011.

[5] J. J. Lu, J. L. Bao, G. S. Wu et al., "Quinones derived from plant secondary metabolites as anti-cancer agents," Anti-Cancer Agents in Medicinal Chemistry, vol. 13, no. 3, pp. 456-463, 2013.

[6] D. R. Avisetti, K. S. Babu, and S. V. Kalivendi, "Activation of p38/JNK pathway is responsible for embelin induced apoptosis in lung cancer cells: transitional role of reactive oxygen species," PLoS One, vol. 9, no. 1, article e87050, 2014.

[7] W. Y. Li, Y. F. Ng, H. Zhang et al., "Emodin elicits cytotoxicity in human lung adenocarcinoma A549 cells through inducing apoptosis," Inflammopharmacology, vol. 22, no. 2, pp. 127134, 2014.

[8] J. N. Li, F. Z. Lv, and J. L. Xiao, "Effects of emodin on proliferation cycle and apoptotic gene of human lung adenocarcinoma cell line Anip 973," Chinese Journal of Integrated Traditional and Western Medicine, vol. 26, no. 11, pp. 1015-7, 1020, 2006.

[9] J. Su, Y. Yan, J. Qu, X. Xue, Z. Liu, and H. Cai, "Emodin induces apoptosis of lung cancer cells through ER stress and the TRIB3/NF- $\kappa$ B pathway," Oncology Reports, vol. 37, no. 3, pp. 1565-1572, 2017.

[10] J. M. Lai, J. T. Chang, C. L. Wen, and S. L. Hsu, "Emodin induces a reactive oxygen species-dependent and ATM-p53Bax mediated cytotoxicity in lung cancer cells," European Journal of Pharmacology, vol. 623, no. 1-3, pp. 1-9, 2009. 
[11] Q. Tang, J. Wu, F. Zheng, S. S. Hann, and Y. Chen, "Emodin increases expression of insulin-like growth factor binding protein 1 through activation of MEK/ERK/AMPK $\alpha$ and interaction of PPAR $\gamma$ and Sp1 in lung cancer," Cellular Physiology and Biochemistry, vol. 41, no. 1, pp. 339-357, 2017.

[12] L. He, J. J. Bi, Q. Guo, Y. Yu, and X. F. Ye, "Effects of emodin extracted from Chinese herbs on proliferation of non-small cell lung cancer and underlying mechanisms," Asian Pacific Journal of Cancer Prevention, vol. 13, no. 4, pp. 1505-1510, 2012.

[13] J. C. Ko, Y. J. Su, S. T. Lin et al., "Suppression of ERCC1 and Rad51 expression through ERK1/2 inactivation is essential in emodin-mediated cytotoxicity in human non-small cell lung cancer cells," Biochemical Pharmacology, vol. 79, no. 4, pp. 655-664, 2010.

[14] F. L. He, L. Wang, X. K. Zhang, and J. Z. Zeng, "Emodin induces apoptosis of cancer cells and inhibits retinoid $\mathrm{X}$ receptor transcriptional activity," Yao xue xue bao= Acta pharmaceutica Sinica, vol. 43, no. 4, pp. 350-355, 2008.

[15] T. P. Xu, H. Shen, L. X. Liu, and Y. Q. Shu, "Plumbagin from Plumbago Zeylanica L induces apoptosis in human nonsmall cell lung cancer cell lines through NF- $\kappa$ B inactivation," Asian Pacific Journal of Cancer Prevention, vol. 14, no. 4, pp. 2325-2331, 2013.

[16] H. B. Wang and X. Q. Ma, “ $\beta, \beta$-Dimethylacrylshikonin induces mitochondria-dependent apoptosis of human lung adenocarcinoma cells_in vitro_via p38 pathway activation," Acta Pharmacologica Sinica, vol. 36, no. 1, pp. 131-138, 2015.

[17] C. H. Ni, C. S. Yu, H. F. Lu et al., "Chrysophanol-induced cell death (necrosis) in human lung cancer A549 cells is mediated through increasing reactive oxygen species and decreasing the level of mitochondrial membrane potential," Environmental Toxicology, vol. 29, no. 7, pp. 740-749, 2014.

[18] Z. L. Ma, B. J. Zhang, D. T. Wang et al., "Tanshinones suppress AURKA through up-regulation of miR-32 expression in nonsmall cell lung cancer," Oncotarget, vol. 6, no. 24, pp. 2011120120, 2015.

[19] J. Zhang, J. Wang, J. Y. Jiang, S. D. Liu, K. Fu, and H. Y. Liu, "Tanshinone IIA induces cytochrome c-mediated caspase cascade apoptosis in A549 human lung cancer cells via the JNK pathway," International Journal of Oncology, vol. 45, no. 2, pp. 683-690, 2014.

[20] Y. Yan, W. Su, S. Zeng et al., "Effect and mechanism of tanshinone I on the radiosensitivity of lung cancer cells," Molecular Pharmaceutics, vol. 15, no. 11, pp. 4843-4853, 2018.

[21] S. Liu, Z. Han, A. L. Trivett et al., "Cryptotanshinone has curative dual anti-proliferative and immunotherapeutic effects on mouse Lewis lung carcinoma," Cancer Immunology Immunotherapy, vol. 68, no. 7, pp. 1059-1071, 2019.

[22] J. Zhang, G. Wen, L. Sun et al., "Cryptotanshinone inhibits cellular proliferation of human lung cancer cells through downregulation ofIGF-1R/PI3K/Akt signaling pathway," Oncology Reports, vol. 40, no. 5, pp. 2926-2934, 2018.

[23] L. Yang, J. Li, L. Xu et al., "Rhein shows potent efficacy against non-small-cell lung cancer through inhibiting the STAT3 pathway," Cancer Management and Research, vol. Volume 11, no. 11, pp. 1167-1176, 2019.

[24] X. B. Zhang, C. L. Zou, Y. X. Duan, F. Wu, and G. Li, “Activity guided isolation and modification of juglone from Juglans regia as potent cytotoxic agent against lung cancer cell lines," BMC Complementary and Alternative Medicine, vol. 15, no. 1, 2015.
[25] L. Wan, L. Zhang, K. Fan, and J. Wang, "Aloin promotes A549 cell apoptosis via the reactive oxygen species-mitogen activated protein kinase signaling pathway and $\mathrm{p} 53$ phosphorylation," Molecular Medicine Reports, vol. 16, no. 5, pp. 57595768, 2017.

[26] Y. Y. Wu, J. H. Zhang, J. H. Gao, and Y. S. Li, “Aloe-emodin (AE) nanoparticles suppresses proliferation and induces apoptosis in human lung squamous carcinoma via ROS generation in vitro and in vivo," Biochemical and Biophysical Research Communications, vol. 490, no. 3, pp. 601-607, 2017.

[27] H. Z. Lee, W. H. Yang, M. J. Hour et al., "Photodynamic activity of aloe-emodin induces resensitization of lung cancer cells to anoikis," European Journal of Pharmacology, vol. 648, no. 1-3, pp. 50-58, 2010.

[28] H. Z. Lee, C. J. Lin, W. H. Yang, W. C. Leung, and S. P. Chang, "Aloe-emodin induced DNA damage through generation of reactive oxygen species in human lung carcinoma cells," Cancer Letters, vol. 239, no. 1, pp. 55-63, 2006.

[29] W. T. Chang, B. J. You, W. H. Yang, C. Y. Wu, D. T. Bau, and H. Z. Lee, "Protein kinase $\mathrm{C}$ delta-mediated cytoskeleton remodeling is involved in aloe-emodin-induced photokilling of human lung cancer cells," Anticancer Research, vol. 32, no. 9, pp. 3707-3713, 2012.

[30] M. Y. Lai, M. J. Hour, H. Wing-Cheung Leung, W. H. Yang, and H. Z. Lee, "Chaperones are the target in aloe-emodininduced human lung nonsmall carcinoma H460 cell apoptosis," European Journal of Pharmacology, vol. 573, no. 1-3, pp. 1-10, 2007.

[31] Y. W. Zhang, Z. X. Zhang, Z. H. Miao, and J. Ding, "The telomeric protein TRF2 is critical for the protection of A549 cells from both telomere erosion and DNA double-strand breaks driven by salvicine," Molecular Pharmacology, vol. 73, no. 3, pp. 824-832, 2008

[32] W. J. Liu, Y. W. Zhang, Y. Shen, J. F. Jiang, Z. H. Miao, and J. Ding, "Telomerase inhibition is a specific early event in salvicine-treated human lung adenocarcinoma A549 cells," Biochemical and Biophysical Research Communications, vol. 323, no. 2, pp. 660-667, 2004.

[33] R. Deng, J. Tang, B. F. Xie et al., "SYUNZ-16, a newly synthesized alkannin derivative, induces tumor cells apoptosis and suppresses tumor growth through inhibition of PKB/AKT kinase activity and blockade of AKT/FOXO signal pathway," International Journal of Cancer, vol. 127, no. 1, pp. 220-229, 2010.

[34] P. Hansakul, K. Aree, S. Tanuchit, and A. Itharat, "Growth arrest and apoptosis via caspase activation of dioscoreanone in human non-small-cell lung cancer A549 cells," BMC Complementary and Alternative Medicine, vol. 14, no. 1, p. 413, 2014.

[35] C. T. Kuo, B. C. Chen, C. C. Yu et al., "Apoptosis signalregulating kinase 1 mediates denbinobin-induced apoptosis in human lung adenocarcinoma cells," Journal of Biomedical Science, vol. 16, no. 1, p. 43, 2009.

[36] C. T. Kuo, M. J. Hsu, B. C. Chen et al., "Denbinobin induces apoptosis in human lung adenocarcinoma cells via Akt inactivation, Bad activation, and mitochondrial dysfunction," Toxicology Letters, vol. 177, no. 1, pp. 48-58, 2008.

[37] R. A. Mothana, R. Jansen, R. Gruenert, P. J. Bednarski, and U. Lindequist, "Antimicrobial and cytotoxic abietane diterpenoids from the roots of Meriandera benghalensis (Roxb.) Benth," Pharmazie, vol. 64, no. 9, pp. 613-615, 2009. 
[38] E. Haque, M. Kamil, S. Irfan et al., "Blocking mutation independent p53 aggregation by emodin modulates autophagic cell death pathway in lung cancer," The International Journal of Biochemistry \& Cell Biology, vol. 96, pp. 90-95, 2018.

[39] Y. C. Li, S. M. He, Z. X. He et al., "Plumbagin induces apoptotic and autophagic cell death through inhibition of the $\mathrm{PI} 3 \mathrm{~K} / \mathrm{Akt} / \mathrm{mTOR}$ pathway in human non-small cell lung cancer cells," Cancer Letters, vol. 344, no. 2, pp. 239-259, 2014.

[40] W. Hao, X. Zhang, W. Zhao et al., "Cryptotanshinone induces pro-death autophagy through JNK signaling mediated by reactive oxygen species generation in lung cancer cells," Anti-Cancer Agents in Medicinal Chemistry, vol. 16, no. 5, pp. 593-600, 2016.

[41] X. Wang, L. Li, R. Guan, D. Zhu, N. Song, and L. Shen, "Emodin inhibits ATP-induced proliferation and migration by suppressing P2Y receptors in human lung adenocarcinoma cells," Cellular Physiology and Biochemistry, vol. 44, no. 4, pp. 13371351, 2017.

[42] S. Ok, S. M. Kim, C. Kim et al., "Emodin inhibits invasion and migration of prostate and lung cancer cells by downregulating the expression of chemokine receptor CXCR4," Immunopharmacology and Immunotoxicology, vol. 34, no. 5, pp. 768-778, 2012.

[43] C. G. Kang, E. Im, H. J. Lee, and E. O. Lee, "Plumbagin reduces osteopontin-induced invasion through inhibiting the Rhoassociated kinase signaling pathway in A549 cells and suppresses osteopontin-induced lung metastasis in BalB/c mice," Bioorganic \& Medicinal Chemistry Letters, vol. 27, no. 9, pp. 1914-1918, 2017.

[44] T. Yu, Y. Y. Xu, Y. Y. Zhang, K. Y. Li, Y. Shao, and G. Liu, "Plumbagin suppresses the human large cell lung cancer cell lines by inhibiting IL-6/STAT3 signaling in vitro," International Immunopharmacology, vol. 55, pp. 290-296, 2018.

[45] J. Yang, X. R. Kuang, P. T. Lv, and X. X. Yan, "Thymoquinone inhibits proliferation and invasion of human nonsmall-cell lung cancer cells via ERK pathway," Tumour Biology, vol. 36, no. 1, pp. 259-269, 2015.

[46] J. Xie, J. Liu, H. Liu et al., "The antitumor effect of tanshinone IIA on anti-proliferation and decreasing VEGF/VEGFR2 expression on the human non-small cell lung cancer A549 cell line," Acta Pharmaceutica Sinica B., vol. 5, no. 6, pp. 554-563, 2015.

[47] H. J. Lee, H. J. Lee, V. Magesh et al., "Shikonin, acetylshikonin, and isobutyroylshikonin inhibit VEGF-induced angiogenesis and suppress tumor growth in Lewis lung carcinoma-bearing mice," Yakugaku Zasshi, vol. 128, no. 11, pp. 1681-1688, 2008.

[48] A. C. Tsai, S. L. Pan, C. Y. Lai et al., "The inhibition of angiogenesis and tumor growth by denbinobin is associated with the blocking of insulin-like growth factor-1 receptor signaling," Journal of Nutritional Biochemistry, vol. 22, no. 7, pp. 625633, 2011.

[49] Y. Zhang, L. Wang, Y. Chen, and C. Qing, “Anti-angiogenic activity of salvicine," Pharmaceutical Biology, vol. 51, no. 8, pp. 1061-1065, 2013.

[50] L. Jin, M. Xu, X. H. Luo, and X. F. Zhu, "Stephania tetrandra and ginseng-containing Chinese herbal formulation NSENL reverses cisplatin resistance in lung cancer xenografts," The American Journal of Chinese Medicine, vol. 45, no. 2, pp. 385-401, 2017.

[51] L. Jiang, J. L. Hao, M. L. Jin, Y. G. Zhang, and P. Wei, “Effect of Embelin on TRAIL receptor $2 \mathrm{mAb}$-induced apoptosis of TRAIL-resistant A549 non-small cell lung cancer cells," Asian
Pacific Journal of Cancer Prevention, vol. 14, no. 10, pp. 6115-6120, 2013.

[52] Y. J. Cheng, H. S. Jiang, S. L. Hsu et al., "XIAP-mediated protection of H460 lung cancer cells against cisplatin," European Journal of Pharmacology, vol. 627, no. 1-3, pp. 75-84, 2010.

[53] Y. Ying, L. Qingwu, X. Mingming, S. Zhenju, T. Chaoyang, and T. Zhengang, "Emodin: one main ingredient of Shufeng Jiedu capsule reverses chemoresistance of lung cancer cells through inhibition of EMT," Cellular Physiology and Biochemistry, vol. 42, no. 3, pp. 1063-1072, 2017.

[54] Y. J. Su, M. S. Tsai, Y. H. Kuo et al., "Role of Rad51 downregulation and extracellular signal-regulated kinases 1 and 2 inactivation in emodin and mitomycin C-induced synergistic cytotoxicity in human non-small-cell lung cancer cells," Molecular Pharmacology, vol. 77, no. 4, pp. 633-643, 2010.

[55] S. Chen, Z. Zhang, and J. Zhang, "Emodin enhances antitumor effect of paclitaxel on human non-small-cell lung cancer cells in vitro and in vivo," Drug Design Development and Therapy, vol. Volume 13, pp. 1145-1153, 2019.

[56] E. O. Kim, S. E. Kang, C. R. Im et al., “Tanshinone IIA induces TRAIL sensitization of human lung cancer cells through selective ER stress induction," International Journal of Oncology, vol. 48, no. 5, pp. 2205-2212, 2016.

[57] Q. Li, K. Hu, S. Tang, L. F. Xu, and Y. C. Luo, “Anti-tumor activity of tanshinone IIA in combined with cyclophosphamide against Lewis mice with lung cancer," Asian Pacific Journal of Tropical Medicine, vol. 9, no. 11, pp. 1084-1088, 2016.

[58] J. Xie, J. H. Liu, H. Liu et al., “Tanshinone IIA combined with adriamycin inhibited malignant biological behaviors of NSCLC A549 cell line in a synergistic way," BMC Cancer, vol. 16, no. 1, p. 899, 2016.

[59] X. Z. Liao, Y. Gao, S. Huang et al., "Tanshinone IIA combined with cisplatin synergistically inhibits non-small-cell lung cancer in vitro and in vivo via down-regulating the phosphatidylinositol 3-kinase/Akt signalling pathway," Phytotherapy Research, vol. 33, no. 9, pp. 2298-2309, 2019.

[60] Y.-Z. Zhen, G. Hu, Y.-F. Zhao et al., "Synergy of taxol and rhein lysinate associated with the downregulation of ERK activation in lung carcinoma cells," Oncology Letters, vol. 6, no. 2, pp. 525-528, 2013.

[61] C. Xia, X. Bai, X. Hou et al., "Cryptotanshinone reverses cisplatin resistance of human lung carcinoma A549 cells through down-regulating Nrf2 pathway," Cellular Physiology and Biochemistry, vol. 37, no. 2, pp. 816-824, 2015.

[62] A. K. Tse, K. Y. Chow, H. H. Cao et al., "The herbal compound cryptotanshinone restores sensitivity in cancer cells that are resistant to the tumor necrosis factor-related apoptosisinducing ligand," Journal of Biological Chemistry, vol. 288, no. 41, pp. 29923-29933, 2013.

[63] J. Zhou, G. Li, G. Han et al., "Emodin induced necroptosis in the glioma cell line U251 via the TNF- $\alpha$ /RIP1/RIP3 pathway," Investigational New Drugs, vol. 38, no. 1, pp. 50-59, 2019.

[64] M. Seo, H. J. Nam, S. Y. Kim, and Y. S. Juhnn, "Inhibitory heterotrimeric GTP-binding proteins inhibit hydrogen peroxideinduced apoptosis by up-regulation of Bcl-2 via NF-kappaB in H1299 human lung cancer cells," Biochemical and Biophysical Research Communications, vol. 381, no. 2, pp. 153-158, 2009.

[65] J. S. M. Richardson, N. Aminudin, and S. N. Abd Malek, "Chalepin: a compound from Ruta angustifolia L. Pers exhibits cell cycle arrest at $\mathrm{S}$ phase, suppresses nuclear factor-kappa B (NF$\kappa \mathrm{B})$ pathway, signal transducer and activation of transcription 
3 (STAT3) phosphorylation and extrinsic apoptotic pathway in non-small cell lung cancer carcinoma (A549)," Pharmacognosy Magazine, vol. 13, no. 3, pp. 489-498, 2017.

[66] C. H. Jung, A. R. Han, H. J. Chung, I. H. Ha, and H. D. Um, "Linarin inhibits radiation-induced cancer invasion by downregulating MMP-9 expression via the suppression of NF- $\kappa \mathrm{B}$ activation in human non-small-cell lung cancer A549," Natural Product Research, vol. 33, no. 24, pp. 3582-3586, 2018.

[67] J. Li, Y. Li, B. Wang, Y. Ma, and P. Chen, "Id-1 promotes migration and invasion of non-small cell lung cancer cells through activating NF- $\kappa$ B signaling pathway," Journal of Biomedical Science, vol. 24, no. 1, p. 95, 2017.

[68] P. Gao, Y. J. Gao, and H. L. Liang, "Effect of NF- $\kappa$ B inhibitor PDTC on VEGF and endostatin expression of mice with Lewis lung cancer," Asian Pacific Journal of Tropical Medicine, vol. 8, no. 3, pp. 220-224, 2015.

[69] M. Galiè, V. Covi, G. Tabaracci, and M. Malatesta, "The role of Nrf2 in the antioxidant cellular response to medical ozone exposure," International Journal of Molecular Sciences, vol. 20, no. 16, p. 4009, 2019.

[70] X. Dong, J. Fu, X. Yin, C. Yang, and J. Ni, “Aloe-emodin induces apoptosis in human liver HL-7702 cells through Fas death pathway and the mitochondrial pathway by generating reactive oxygen species," Phytotherapy Research, vol. 31, no. 6, pp. 927-936, 2017.

[71] S. Zhu, J. Jin, Y. Wang et al., "The endoplasmic reticulum stress response is involved in apoptosis induced by aloeemodin in HK-2 cells," Food and Chemical Toxicology, vol. 50, no. 3-4, pp. 1149-1158, 2012.

[72] K. Oshida, M. Hirakata, A. Maeda, T. Miyoshi, and Y. Miyamoto, "Toxicological effect of emodin in mouse testicular gene expression profile," Journal of Applied Toxicology, vol. 31, no. 8, pp. 790-800, 2011.

[73] A. R. Anuf, R. Ramachandran, R. Krishnasamy, P. S. Gandhi, and S. Periyasamy, "Antiproliferative effects of Plumbago rosea and its purified constituent plumbagin on SK-MEL 28 melanoma cell lines," Pharmacognosy Research, vol. 6, no. 4, pp. 312-319, 2014.

[74] J. Demma, K. Hallberg, and B. Hellman, "Genotoxicity of plumbagin and its effects on catechol and NQNO-induced DNA damage in mouse lymphoma cells," Toxicology In Vitro, vol. 23, no. 2, pp. 266-271, 2009.

[75] C. P. Yu, C. S. Shia, H. J. Lin, Y. W. Hsieh, S. P. Lin, and Y. C. Hou, "Analysis of the pharmacokinetics and metabolism of aloe-emodin following intravenous and oral administrations in rats," Biomedical Chromatography, vol. 30, no. 10, pp. 1641-1647, 2016.

[76] J. Zhou, J. Zheng, Y. Zhang et al., "Chitosan hydrogel delivery system containing herbal compound functions as a potential antineuroinflammatory agent," ACS Omega, vol. 4, no. 6, pp. 10185-10191, 2019.

[77] B. K. Aithal, M. R. Sunil Kumar, B. N. Rao et al., "Evaluation of pharmacokinetic, biodistribution, pharmacodynamic, and toxicity profile of free juglone and its sterically stabilized liposomes," Journal of Pharmaceutical Sciences, vol. 100, no. 8, pp. 3517-3528, 2011.

[78] L. Zhang, J. H. Chang, B. Q. Zhang et al., "The pharmacokinetic study on the mechanism of toxicity attenuation of rhubarb total free anthraquinone oral colon-specific drug delivery system," Fitoterapia, vol. 104, pp. 86-96, 2015. 